\title{
Expression of Cloned Genes Using the Baculovirus Expression System
}

\author{
Clara L. Kielkopf, William Bauer, and Ina L. Urbatsch
}

The general strategy of the baculovirus expression system is to infect insect cells with a virus that expresses a foreign protein at a very late stage of infection. Almost all baculovirus expression systems use the procedures for insect cell transfection, baculovirus production, and protein expression given in the main portion of this protocol. This protocol also includes a method that uses molecular biology techniques to produce recombinant baculovirus DNA in E. coli before transfection of insect cells. It is important to quantify the viral titer to achieve optimal and reproducible expression of target proteins. Accordingly, the viral plaque assay is also described here.

It is essential that you consult the appropriate Material Safety Data Sheets and your institution's Environmental Health and Safety Office for proper handling of equipment and hazardous materials used in this protocol.

RECIPES: Please see the end of this protocol for recipes indicated by $<R>$. Additional recipes can be found online at http://cshprotocols.cshlp.org/site/recipes.

\section{Reagents}

Agarose, low-melting temperature (e.g., Sigma-Aldrich Type VIII A4018) (for the plaque assay in Steps 27-40 only)

A stock of $5 \%(w / v)$ low-melting-temperature agarose in distilled, deionized water should be sterilized by autoclaving, divided into 5- $\mathrm{mL}$ aliquots in sterile $50-\mathrm{mL}$ tubes, and stored solidified at room temperature until Step 33.

Baculoviral or bacmid DNA suitable for recombination with the transfer vector of choice For example, BacMagic (Merck Biosciences), flashBac (Oxford Expression Technologies), or ProGreen (AB Vector) (for production of recombinant bacmid DNA, see Steps 41-43)

Competent E. coli DH10Bac cells (for the production of bacmid DNA in Steps 41-43 only) The bacmid that contains the baculovirus DNA, bMON14272 (136 kb), is present in the DH1OBac cells and confers resistance to kanamycin. The bacmid also contains a lacZ $\beta$-galactosidase gene that produces blue color in the presence of IPTG/X-Gal unless replaced by recombination with the transfer plasmid.

The helper plasmid pMON7124 (13.2 kb) encodes a Tn7 transposase and confers resistance to tetracycline (Barry 1988).

Coomassie Brilliant Blue R-250 stain solution $<\mathrm{R}>$

Fetal bovine serum

Gene or cDNA fragment of interest

From the Molecular Cloning collection, edited by Michael R. Green and Joseph Sambrook.

(c) 2020 Cold Spring Harbor Laboratory Press

Cite this protocol as Cold Spring Harb Protoc; doi:10.1101/pdb.prot102152 
C.L. Kielkopf et al.

Growth medium appropriate for cells used

Insect cell culture medium (for the plaque assay in Steps $27-40$ only)

$1 \times$ medium can be used. If preferred, $1.3 \times$ or $2 \times$ stocks can be used in Step 32 after modifying the volumes (and as needed, addition of sterile water) to achieve final concentrations of $1 \% \mathrm{w} / \mathrm{v}$ agarose and $1 \times$ medium in the overlay. Serum-free or serum-containing medium can be used with appropriately adapted cells.

LB (Luria-Bertani) liquid medium $<\mathrm{R}>$

Luria Broth (LB) agar plates (containing $50 \mu \mathrm{g} / \mathrm{mL}$ kanamycin, $7 \mu \mathrm{g} / \mathrm{mL}$ gentamicin, $10 \mu \mathrm{g} / \mathrm{mL}$ tetracycline, $100 \mu \mathrm{g} / \mathrm{mL}$ X-Gal, $40 \mu \mathrm{g} / \mathrm{mL}$ IPTG)

Luria Broth (LB) liquid medium (with and without a mixture of $50 \mu \mathrm{g} / \mathrm{mL}$ kanamycin, $7 \mu \mathrm{g} / \mathrm{mL}$ gentamicin, $10 \mu \mathrm{g} / \mathrm{mL}$ tetracycline antibiotics) (for the production of bacmid DNA in Steps 41-43 only)

Liposome transfection reagent (store at $4^{\circ} \mathrm{C}$ until use; see Step 4)

For example, Bacfectin (Clontech), Escort or Escort IV (Sigma-Aldrich), FuGENE (Promega), Gene/uice (Merck), Lipofectin or Cellfectin II (Life Technologies), Tfx-20 (Promega), among others.

Neutral Red stock solution $(5 \mathrm{mg} / \mathrm{mL}$ in distilled deionized water) (for the plaque assay in Steps $27-40$ only)

Sterilize by $0.22-\mu \mathrm{m}$ filtration and store at room temperature.

pFastBac vector containing the gene for the protein of interest $(0.2 \mathrm{ng} / \mu \mathrm{L}$ in TE buffer) (for the production of bacmid DNA in Steps 41-43 only)

The pFastBac vectors confer resistance to gentamicin and ampicillin.

Phosphate-buffered saline (PBS) $<\mathrm{R}>$

Prepare $10 \times$ PBS (no $\mathrm{CaCl}_{2}$ or $\mathrm{MgCl}_{2}$ ). $1 \times$ PBS is prepared by diluting $10 \times \mathrm{PBS}$ stock in sterile water. The final $\mathrm{pH}$ of the diluted $1 \times$ PBS should be 7.4 , although the $\mathrm{pH}$ of the $10 \times$ stock may be lower. Adjust the $\mathrm{pH}$ with $1 \mathrm{~N} \mathrm{HCl}$ if necessary.

Polyacrylamide gel containing sodium dodecyl sulfate (SDS)

Positive control transfer vector

Expression systems that generate a fusion with a fluorescent protein such as GFP can be monitored directly (Fig. 1). Other commercial expression systems are usually provided with control vectors that carry the same promoter and express a protein that can be detected by colorimetric assays. For example, the pBACgus-1 (Merck Biosciences) plasmid expresses a $\beta$-glucuronidase enzyme that produces a blue color in the presence of X-glucuronide.

SDS gel-loading buffer $(6 \times)$

Store $6 \times$ SDS loading buffer lacking dithiothreitol at room temperature. Add dithiothreitol to a final concentration of $100 \mathrm{~mm}$ from a $1 \mathrm{~m}$ stock just before the buffer is used.

A

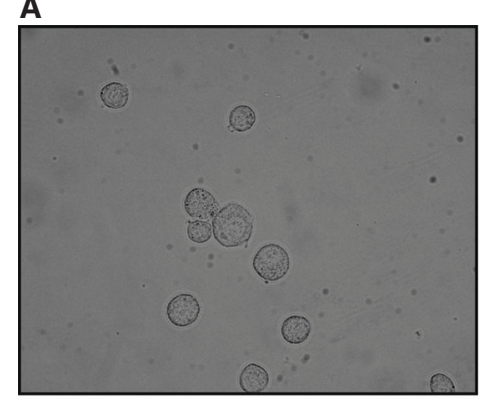

B

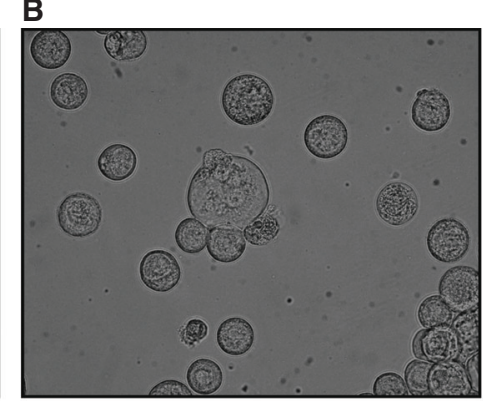

C

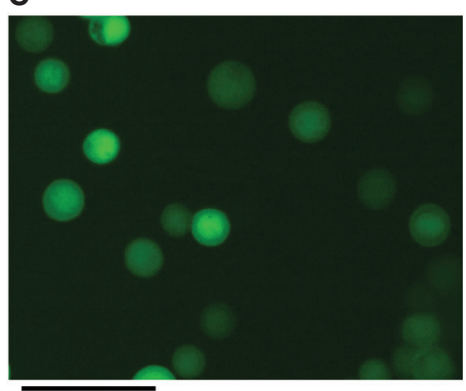

FIGURE 1. Changes in the appearance of baculovirus-infected insect cells. Tn-5 cells uninfected $(A)$ and infected $(B, C)$ with baculovirus generated using a pVL1393-based transfer vector and linearized ProGreen genomic baculovirus vector DNA. The infected cells express GFP encoded in the ProGreen DNA. Panel $C$ is a fluorescence image of the same cells as shown in $B$ with phase-contrast illumination. Note that the infected cells are on average slightly larger than the uninfected cells. Scale bar, $100 \mu \mathrm{m}$. (Photographs courtesy of Drs. Jost Vielmetter and Inderjit Nangiana, Caltech Protein Expression Facility.) 
Serum-free insect cell culture medium

Several commercial options are available for serum-free media, for example, Sf-900 III (Life Technologies), HyQR SFX-Insect (Hyclone), and BD Baculogold Max-XP (BD Biosciences). These media are complete and already contain surfactants, thus Pluronic F-68 should not be added.

Spodoptera frugiperda Sf-9 or Sf-21 cells adapted to the appropriate medium See Box 1. For the plaque assay in Steps 27-40, use cells from Step 2.

Transfer vector containing your insert

Trypan Blue stock solution $(0.4 \%, \mathrm{w} / \mathrm{v})$

$\mathrm{X}$-Gal stock solution ( $40 \mathrm{mg} / \mathrm{mL} \mathrm{X}$-Gal [5-bromo-4-chloro-3-indoyl- $\beta$-D-galactopyranoside] in dimethylformamide) (for the plaque assay in Steps 27-40 only)

Store at $-20^{\circ} \mathrm{C}$ in the dark.

Equipment

Baffled shake flask with cap (1000 mL), sterile (e.g., Kimble-Chase part no. 25630-1000 and Corning closure 38-mm polypropylene part no. 430621-0000)

Beckman JA10, Sorvall GS3 or SLA3000 rotor, or equivalent rotor with $500-\mathrm{mL}$ centrifuge bottles Beckman JA20, Sorvall SS34 or SA600 rotor, or equivalent rotor with 40- to 50-mL centrifuge bottles Dry heat block (optional; see Step 33)

Heat block set at $85^{\circ} \mathrm{C}$ or boiling water bath

Hemocytometer

Inverted microscope (for the plaque assay in Steps $27-40$ only)

Inverted phase-contrast microscope

Laminar flow tissue culture hood

Liquid nitrogen

Microcentrifuge tubes, sterile

These are almost always polypropylene and thus should not be used for liposome-containing transfection mixtures.

Shaking incubator set at $28^{\circ} \mathrm{C}$

Stationary incubator set at $28^{\circ} \mathrm{C}$

Tissue culture dishes ( $35 \mathrm{~mm}$, six-well plate; and $150 \mathrm{~mm}$, 24-well plate), polystyrene

Because DNA-lipid complexes adsorb on glass or polypropylene surfaces during liposome-mediated transfection, polystyrene dishes should be used.

\section{BOX 1. INSECT CELL LINES USED FOR PROTEIN EXPRESSION}

Only a handful of insect cell lines are commonly used for protein expression, despite the existence of more than 260 documented insect cell lines (Lynn 2007). Traditionally, either of two S. frugiperda cell lines is used: IPLB-Sf-21AE (Sf-21) derived from pupal ovaries or its clonal isolate SF-9 (Vaughn et al. 1977). Further transgenic variants of $S$. frugiperda cell lines have been engineered to produce terminally sialylated $\mathrm{N}$ glycoproteins resembling those of mammalian cells (SfSWT-1 or Mimic from Life Technologies and SfSWT-3) (Hollister et al. 2002; Aumiller et al. 2003). Two Trichoplusia ni cell lines are popular: TN-368 derived from adult ovaries (Hink 1970) and BTI-TN-5B1-4 derived from embryos (Tn-5, commercially known as the High-Five line from Life Technologies) (Granados et al. 1986). The Tn-5 cell line has been reported to produce exceptionally high levels of recombinant proteins, particularly when the protein is secreted (e.g., Wickham et al. 1992; Davis et al. 1993; Wickham and Nemerow 1993). However, the $T$. ni cells tend to aggregate when grown as suspension cultures in the absence of heparin (Wickham and Nemerow 1993; Dee et al. 1997). Furthermore, the rates of mutation and efficiency of transfection are reported to be lower for the T. ni cells than for S. frugiperda cells. Thus, the Sf-9 or Sf-21 cell lines are suggested as an initial starting point, given their capacity to grow in both suspension and monolayers and their production of both recombinant baculovirus and proteins. 
C.L. Kielkopf et al.

Tissue culture plates, six well (for the plaque assay in Steps $27-40$ only)

Tube $(50 \mathrm{~mL})$, sterile

Tubes with caps $(2-7 \mathrm{~mL})$, polystyrene, sterile (e.g., Greiner Bio-One part no. 189171)

Tubes with caps $(15 \mathrm{~mL})$, sterile

Vortex machine (for the plaque assay in Steps $27-40$ only)

Water bath set at $37^{\circ} \mathrm{C}$

Water bath $\left(40^{\circ} \mathrm{C}\right)$ (for the plaque assay in Steps $27-40$ only)

\section{METHOD}

\section{Transfection of Insect Cells to Generate Recombinant Baculovirus}

1. Insert the DNA fragment containing the $\mathrm{CDNA} /$ gene of interest into a transfer vector for incorporation into the baculovirus genome. Ensure that the cloning strategy will position the proteincoding sequence in a reading frame compatible with the translation signals of the vector. For absent or amino-terminal fusion tags, an in-frame stop codon may need to be included at the $3^{\prime}$ terminus of the protein-coding sequence.

Constructs generated by PCR should be sequenced to ensure that no spurious mutations were introduced during the amplification reactions.

For producing recombinant bacmid DNA, see Steps 41-43 (Bac-to-Bac System, Life Technologies).

2. Expand the Sf-9 or Sf-21 cells that you will need for your transfection experiment in serumfree medium. Use low-passage-number (2-20) cultures in exponential-phase growth (1.5-2.5 $\times$ $10^{6}$ cells $/ \mathrm{mL}$ ). Check that the viability of the cells is $>95 \%$.

For more information on insect cell culture, see Box 2.

SF-9 or SF-21 cells adapted to suspension or monolayer cultures may be used to produce recombinant baculovirus. Tn-5 cells are not recommended for this procedure.

Serum forms complexes with DNA-liposome mixtures and may reduce transfection efficiency. Optimally, insect cells should be adapted to serum-free medium before liposome-mediated transfection. In this case, cells previously grown in serum-containing medium must be sequentially subcultured in $25 \%, 50 \%$, and $100 \%(\mathrm{v} / \mathrm{v})$ mixtures of serum-free and serum-containing medium over a period of $\sim 7 \mathrm{~d}$. Alternatively, (1) cells may be washed and transfected with DNA-liposomes in serum-free medium, then returned to serumcontaining medium at Step 5 to produce the recombinant baculovirus; or (2) calcium phosphate-mediated transformation may be used (as described in Burand et al. 1980).

\section{BOX 2. MAINTAINING AND PROPAGATING INSECT CELL CULTURES}

A practical overview of insect cell culture techniques is summarized here. In-depth techniques are available from several excellent books and reviews, including Lynn (2002) and O'Reilly et al. (1994). Insect cells sequentially progress through lag, exponential, and stationary growth phases typical of other cell types. An approximate rule-of-thumb for insect cell doubling time is $1 \mathrm{~d}$ during the exponential growth phase, with the caveat that the exact time depends on the cell strain, medium, and growth conditions. Insect cells are cultured at $27^{\circ} \mathrm{C}-28^{\circ} \mathrm{C}$ and transferred in a laminar flow hood that has been previously wiped with a disinfectant such as $70 \%$ ethanol. No special $\mathrm{CO}_{2}$ supply is required because insect cell media do not depend on carbonate buffers.

\section{Media}

Insect cells traditionally are cultured in basal media such as Grace's medium (Grace 1962), TNM-FH (Hink 1970), or TC-100 (Gardiner and Stockdale 1975) supplemented with $5 \%-10 \%$ fetal bovine serum (FBS). Serum-free media, developed in the 1980s, has become popular because of advantages that include compatibility with liposome-mediated transfection, reduced lot-to-lot variability, lower background for protein 


\section{BOX 2. Continued}

purification, and, in some cases, lower cost (Agathos 2007). Reliable serum-free media for insect cell culture are available from several sources, including Sf-900 III (Life Technologies), HyQ SFX Insect (HyClone), and BD BaculoGold Max-XP (BD Biosciences) among others. Insect cells should be gradually adapted to any changes in growth media, for example, to transfer from FBS-containing medium to serum-free medium.

\section{Propagation}

Although insect cells may be propagated in suspension or monolayer cultures, it is convenient to continually maintain a stock of Sf-9 or Sf-21 cells in suspension. Even when propagated in suspension cultures, insect cells retain the ability to adhere readily to surfaces and thus can be used to either seed monolayer cultures for virus generation or suspension cultures for protein production. Insect cells adapted to suspension culture in serum-free medium may be purchased directly from a supplier. In contrast, insect cells propagated as adherent cultures must be adapted gradually to suspension conditions. With each subculture, the shaking or stirring rates are slowly increased in increments of $5 \mathrm{rpm}$ per passage, from 90 to achieve $130 \mathrm{rpm}$ for shaken cultures or from 40 to achieve $90 \mathrm{rpm}$ for stirred cultures.

\section{Equipment}

The shaker/incubator and flasks required to shake insect cell cultures in suspension are no different from those commonly used for bacterial cell growth but should be dedicated to use with insect cells to avoid contamination. Alternatively, spinner flasks may be purchased, placed within a standing incubator, and driven by magnetic stir plates. Glassware must be rinsed thoroughly to remove all traces of detergent, which inhibits insect cell growth. To allow proper aeration, the volumes used for shaken cultures should not exceed one-third of the flask volume (one-half of the volume for baffled flasks), and the volumes used for spinner cultures should not exceed two-thirds of the flask volume. In all cases, the caps should be loose. An advantage of suspension cultures is that cells can be easily withdrawn to monitor the cell density and viability, most often using a hemocytometer. For most types of hemocytometers, one cell per one small square corresponds to $10^{4}$ cells $/ \mathrm{mL}$. To determine cell viability, addition of $0.1 \mathrm{~mL}$ of $0.4 \%$ Trypan Blue to $1 \mathrm{~mL}$ of log-phase cells will color dead cells blue; inspect using a microscope. Although it is more costly, you may prefer to purchase a Coulter particle counter or a Vi-CELL to determine the cell density.

\section{Culture}

Cultured insect cells should be maintained in an exponential growth phase $\left(\sim 2 \times 10^{6}\right.$ cells $\left./ \mathrm{mL}\right)$ at $>90 \%$ viability. The cells should be diluted from a frozen stock or an exponential-growth-phase culture to a density of $3 \times 10^{5}$ cells $/ \mathrm{mL}$ in an appropriate volume of medium, for example, by adding $4.5 \mathrm{~mL}$ of $2 \times 10^{6} \mathrm{cells} / \mathrm{mL}$ culture to $30 \mathrm{~mL}$ of medium in a $125-\mathrm{mL}$ shaker flask (see last paragraph below). After reaching an exponential growth phase $\left(1-3 \times 10^{6}\right.$ cells $\left./ \mathrm{mL}, \sim 2-3 \mathrm{~d}\right)$, the cells should be subcultured by diluting to $3 \times$ $10^{5} \mathrm{cell} \mathrm{s} / \mathrm{mL}$ in fresh medium. At this stage, the volume of the culture may be expanded to achieve the number of cells needed for protein expression. In this manner, an initial 30-mL culture can be expanded to $1 \mathrm{~L}$ of exponential-growth-phase cells for protein production in three passages, or $\sim 11-12 \mathrm{~d}$. Simply diluting the cells to a lower density in a larger volume is not recommended because the cells will return to a lag phase and divide very slowly. Conversely, never allow the cell cultures to overgrow and enter the stationary phase $\left(>4 \times 10^{6}\right.$ cells $/ \mathrm{mL}$ for most cultures). Every $3 \mathrm{wk}$, the cell culture medium should be replaced to avoid the buildup of toxic by-products. Centrifuge the cultures in sterile tubes at $400 \mathrm{~g}$ for $10 \mathrm{~min}$, and then gently resuspend the cell pellet in an appropriate volume of fresh medium. After resuspension, check that the cells remain intact and viable.

The number of times the cells may be subcultured is not indefinite. At high passage ( $>40$ rounds of subculture), the ability of the cells to produce protein is likely to deteriorate. It is prudent to expand an insect cell culture in approximately the first three to four passages and cryopreserve a large number of vials. These freezer stocks can then be used to seed fresh cultures when the passage number of the working cell culture becomes high or if contamination occurs. Healthy, mid-exponential-growth-phase cells should be resuspended in cold cryoprotection medium ( $45 \%$ fresh medium, $45 \%$ of the current medium after $0.22-\mu \mathrm{m}$ sterile filtration, and $10 \%$ DMSO) at a cell density of $1-2 \times 10^{6}$ cells $/ \mathrm{mL}$. Aliquots in $50-\mathrm{mL}$ cryovials (e.g., Corning, no. 430656) are frozen gradually by placement for $30 \mathrm{~min}$ at $4{ }^{\circ} \mathrm{C}$, for $3-4 \mathrm{~h}$ at $-20^{\circ} \mathrm{C}$, and overnight at $-80^{\circ} \mathrm{C}$, and are then stored in liquid nitrogen. 
BOX 2. Continued

Note that if starting an initial insect cell culture from a frozen stock, first wash the cells to remove the DMSO as follows:

1. Thaw the cells rapidly at $37^{\circ} \mathrm{C}$ and dilute in $10 \mathrm{~mL}$ of medium.

2. Centrifuge at $400 \mathrm{~g}$ for $10 \mathrm{~min}$.

3. Gently resuspend the cell pellet in $5 \mathrm{~mL}$ of fresh medium.

4. Count and determine the viability of the cells before seeding the culture.

\section{Considerations for Lysis of Insect Cells}

Insect cells are relatively fragile and easily lysed compared with $E$. coli or yeast host cells. A gentle sonication procedure can be used to lyse insect cells for purification of intracellular proteins (for an example of this procedure, see Altmann et al. 1995).

\section{Sonication}

1. Resuspend insect cells at a density of $10^{7}$ cells $/ \mathrm{mL}$ in an appropriate buffer for purification (e.g., $20 \mathrm{~mm}$ sodium phosphate at $\mathrm{pH} 7.4,0.5 \mathrm{M} \mathrm{NaCl}$ ). Reducing agents, protease inhibitors (e.g., $1 \mathrm{~mm}$ PMSF, $1 \mathrm{~mm}$ DTT, 0.5 mм EDTA), RNase, and DNase (see Step 2) may be added.

If the sample is to be used in IMAC purification (Protocol: Purification of Polyhistidine-Tagged Proteins by Immobilized Metal Affinity Chromatography [Kielkopf et al. 2020a]), then omit the DTT and EDTA. These reagents will interfere with the resin's ability to bind the target histidines.

If needed, additional protease inhibitors-including leupeptin or benzamidine for serine proteases, E-64 for cysteine proteases, and/or pepstatin A for aspartic proteases-may be included. Inhibitor stocks are prepared as follows: $10 \mathrm{mg} / \mathrm{mL}$ leupeptin in water, $2.5 \mathrm{mg} / \mathrm{mL}$-64 in water, and $10 \mathrm{mg} / \mathrm{mL}$ pepstatin A in dry DMSO. Stocks are used at a 1000-fold dilution. Benzamidine is prepared at $250 \mathrm{~mm}$ in water and used at a 100-fold dilution. All stocks should be frozen in aliquots to avoid repeated freeze-thaw cycles.

2. Sonicate cells briefly for three 10 -sec pulses at $30 \mathrm{~W}$ with chilling in an ice bath.

After sonication, DNase I may be added to a final concentration of $0.1 \mathrm{mg} / \mathrm{mL}$ and $\mathrm{MgCl}_{2}$ to a final concentration of $1 \mathrm{mM}$.

3. Remove cell debris by centrifugation at $10,000 \mathrm{~g}$ for $10 \mathrm{~min}$ before the protein is purified from the supernatant.

4. Monitor the progress of cell lysis by light microscopy or by immunoblotting the supernatant and pellet fractions.

\section{Mechanical Lysing}

Insect cell samples also can be mechanically lysed using a dounce homogenizer or by passing through a needle (Wadzinski et al. 1992; Gimpl et al. 1995).

\section{Nonionic Detergent}

Alternatively, if detergents do not interfere with subsequent purification steps or applications, insect cells may be lysed by including a nonionic detergent, such as 1\% IGEPAL CA-630 (the equivalent of Nonidet P40, which is no longer commercially available) (for an example of this procedure, see Licari and Bailey 1991). A variety of insect cell lysis reagents based on nonionic detergents are commercially available, including I-PER (Pierce) and Insect Cell Lysis Buffer (BD Biosciences).

1. Resuspend cells at a density of $0.25 \times 10^{7}$ to $0.5 \times 10^{7}$ cells $/ \mathrm{mL}$ in buffer containing appropriate reducing agents, protease inhibitors, RNase, and DNase as described above for Sonication.

2. Incubate on ice for $20 \mathrm{~min}$ in the presence of the detergent.

3. Remove cell debris by centrifugation before the protein is purified from the supernatant.

3. Seed the dishes with insect cells. Prepare and label the appropriate number of $35-\mathrm{mm}$, polystyrene cell culture dishes: one for each recombinant virus as well as for the positive and negative (no DNA) controls. Provide sufficient cells to achieve a subconfluent (50\%-70\%) surface density. For 
each 35 -mm dish, add $\sim 1 \times 10^{6}$ cells in a 2 -mL volume of medium. Place the culture dishes on a level surface and allow the cells to attach for $60 \mathrm{~min}$ at room temperature.

Do not use antibiotics during transfection because this causes cell death.

4. While the cells are attaching, prepare the mixture of DNA and transfection reagent. Incubate 100$250 \mathrm{ng}$ of viral DNA with fivefold to 10 -fold excess of transfer vector for $5 \mathrm{~min}$ in a microcentrifuge tube. For each planned plate, combine $200 \mu \mathrm{L}$ of serum-free medium with $6 \mu \mathrm{L}$ of transfection reagent in a sterile polystyrene tube and vortex briefly to mix. Add the experimental and positive control DNA mixtures to each aliquot and mix by gently inverting. Prepare an additional tube of the transfection reagent/medium mixture in the absence of DNA for use as a negative control. Incubate the final mixtures for $15-30 \mathrm{~min}$ at room temperature while the liposome-DNA complexes form. After the incubation period, add $800 \mu \mathrm{L}$ of additional serumfree medium to a total volume of $1 \mathrm{~mL}$ per planned dish.

This protocol is a starting point for reagents based on the synthetic lipid $N$-[1 (2,3-dioleoyloxy) propyl]- $N, N$, $\mathrm{N}$-trimethylammonium chloride (DOTAP) mixed with dioleoyl phosphatidylethanolamine (DOPE), such as found in Lipofectin (Life Technologies), Bacfectin (Clontech), GeneJuice (Merck), Escort, or Escort IV (Sigma-Aldrich) reagents. If necessary, modify to suit the manufacturer's guidelines for the specific transfection reagent chosen.

The DNA used for transfection should be of high purity, for example, from anion-exchange chromatography using kits available from several manufacturers (e.g., PureLink HiPure Plasmid DNA Miniprep Kit, Life Technologies; QIAEX resin, QIAGEN). The large viral and bacmid DNAs are subject to shearing. Vortexing should be avoided, and wide-mouth pipette tips should be used to handle high-molecular-weight DNA. These large DNAs should be purified within a few weeks of the time of transfection and not subjected to freeze-thaw cycles.

Transfection conditions can be optimized by varying the amounts of DNA or transfection reagent.

For the BaculoDirect system, use the Gateway recombination reaction directly. For the Bac-to-Bac system, use 1-2 $\mu$ g of purified bacmid DNA (for construction of recombinant bacmid DNA, see Steps 41-43).

5. Remove the medium supernatant from the immobilized cells. Immediately add $1 \mathrm{~mL}$ of DNAliposome-containing medium dropwise to the center of each dish. Incubate for $5 \mathrm{~h}$ or overnight at $28^{\circ} \mathrm{C}$.

To avoid disturbing the cells, tip the dish at a $30^{\circ}-60^{\circ}$ angle so that the liquid pools to one side of the dish and remove with a sterile pipette.

Do not let the cell layer dry out.

6. Remove the medium from the experimental and positive control plates, and replace it with $2 \mathrm{~mL}$ of appropriate growth medium. Incubate at $28^{\circ} \mathrm{C}$.

Antibiotics may be used in this step if desired. However, antibiotics are not recommended during insect cell culture because they may mask microbial contamination.

If the cells have been maintained in complete growth medium supplemented with serum, then use this type of medium at this step.

A nearby pan of water or enclosure of the plate in a plastic bag will reduce evaporation during the incubation period.

7. Cultures may be inspected after $2-3 \mathrm{~d}$ for changes associated with baculovirus infection (as described below for Step 12) to assess the efficiency of the transfection and recombination reactions.

8. After 4-5 d of infection, collect and transfer the medium, which contains the recombinant Passage 1 (P1) virus, to a sterile $15-\mathrm{mL}$ tube. Remove the cell debris by centrifugation at $1000 \mathrm{~g}$ for $10 \mathrm{~min}$ at $4^{\circ} \mathrm{C}$. Transfer the supernatant to a fresh $15-\mathrm{mL}$ tube. This is the P1 viral stock.

The $P 1$ viral stock may be stored protected from light for several months at $4^{\circ} \mathrm{C}$. Addition of $5 \%-10 \%$ fetal bovine serum to the medium will stabilize the baculovirus during storage. This P1 stock should be stored for future amplifications.

Plaque purification to isolate a single recombinant virus before amplification is not necessary for commercial systems that produce $>99 \%$ recombinant viruses, such as flashBAC, BacMagic, ProEasy, and Bac-to-Bac 
C.L. Kielkopf et al.

systems. For other systems that may contain nonrecombinant virus, plaque purification is recommended (see Steps 27-40).

If desired, the baculovirus titer (see Steps 27-40) may be checked before proceeding with amplification. However, traits observed at Steps 6 and 7, including the cessation of cell division, cell detachment, and enlarged nuclei, provide a qualitative indication that infective baculovirus has been produced. Constructs that coexpress GFP (e.g., using pVL-GFP, ProGreen, or BaculoGold Bright) allow the success of virus production to be checked by simply viewing under a fluorescence microscope (Fig. 1).

\section{Amplification of Recombinant Baculovirus to Produce Higher-Titer Stocks}

9. Expand the SF-9 or SF-21 cells as described in Step 2 to provide $2 \times 10^{7}$ cells for each experimental sample of baculovirus, as well as for the positive and negative (no virus) controls.

If simultaneously amplifying a positive control, be careful to avoid cross-contamination of virus.

A negative (no virus) control is helpful for monitoring the progress of infection by comparing cell growth rates and appearance.

10. Label the appropriate number of 150 -mm dishes for insect cells. For each dish, seed $1 \times 10^{6}$ cells/ $\mathrm{mL}$ in a $20-\mathrm{mL}$ volume of medium. Allow the cells to attach for $60 \mathrm{~min}$ at room temperature making sure the culture dishes are level. Then remove the old medium and replace with $20 \mathrm{~mL}$ of fresh medium.

11. Add $500 \mu \mathrm{L}$ of $\mathrm{P} 1$ baculovirus to the plate. Rock the plate gently to distribute the virus, and then place it in a $28^{\circ} \mathrm{C}$ incubator.

To reduce the accumulation of mutations, the multiplicity of infection (MOI, the number of virus particles divided by the number of cells) should be optimally $\sim 0.1$, and certainly $<1.0$ during virus amplification. In the absence of a plaque assay, a rule-of-thumb value of $10^{6}-10^{7} \mathrm{pfu} / \mathrm{mL}$ (pfu is plaque-forming units, infective virus particles) is often assumed for the P1 viral stocks produced by most commercial systems. Using this assumption with the volumes given here:

$$
\text { MOI }=\frac{[(0.5 \times 107 \mathrm{pfu} / \mathrm{mL}) \times(0.5 \mathrm{~mL})]}{\left(2 \times 10^{7} \text { cells }\right)}=0.125
$$

12. After 2-3 d of infection, visually inspect the cells for signs of baculovirus infection. Visible changes to be expected include increased size of the nuclei, increased cell size, granular appearance due to vesicle budding, cell detachment, and, ultimately, cell lysis (Fig. 1A,B). Infected samples are expected to exhibit reduced cell division rates, unlike the negative (no DNA) control, which is expected to continue growth. Viral DNAs or transfer vectors are available for coexpression or fusion of the target protein with GFP (e.g., using pVL-GFP, ProGreen, or BaculoGold Bright). Visualization of GFP using a fluorescence microscope allows the success or failure of virus production to be assessed early in the process (Fig. 1C).

If the cell counts increase above $\sim 4 \times 10^{6}$ cells $/ \mathrm{mL}$ by the fifth day or if the cells do not show morphological changes, then active virus was not produced. Do not proceed further. Failure of the baculovirus to amplify is likely due either to cells that were not healthy or were not in log-phase growth, or from using a high MOI so that all cells in the culture are infected initially.

13. After $4-5 \mathrm{~d}$ of infection, collect and transfer the medium, which contains the recombinant virus, to a sterile $50-\mathrm{mL}$ tube. Remove the cell debris by centrifugation at $1000 \mathrm{~g}$ for $5 \mathrm{~min}$ at $4^{\circ} \mathrm{C}$. Transfer the supernatant to a fresh $50-\mathrm{mL}$ tube. This is the $\mathrm{P} 2$ viral stock.

14. To achieve an optimal baculovirus concentration for protein expression $\left(>10^{8} \mathrm{pfu} / \mathrm{mL}\right)$, Steps $8-$ 13 are usually repeated on a larger scale to obtain a P3 stock (e.g., by doubling the above volumes). Further passages are not recommended because of the accumulation of mutant virus.

The titer of the $P 2$ viral stock is usually $10^{7}-10^{8} \mathrm{pfu} / \mathrm{mL}$.

If desired, the titer of the $P 2$ or $P 3$ virus may be determined as described in Steps 27-40 or with the assistance of a commercial kit. However, bear in mind that determining the titer may take as long as continuing to either the $P 3$ round of amplification or the small-scale tests of protein expression. 


\section{Small-Scale Test and Optimization of Target Protein Expression in Insect Cells}

15. Expand the desired cell line for protein expression [e.g., SF-9, SF-21, Tn-5 (High-Five), or Mimic Sf- 9 cells] as described in Step 2 to provide $\sim 0.5 \times 10^{7}$ cells in exponential growth phase.

Tn-5 cells are reported to express high levels of target proteins, particularly secreted proteins (Davis et al. 1993). (For further details on using Tn-5 cells, see Box 3.) The Mimic SF-9 cells have been engineered to produce terminally sialylated N-glycans as found in mammalian cells (Jarvis et al. 1998).

16. The ratio of virus to cells (MOI) and time of harvest are optimized in an initial expression test. If the titer of the virus is unknown, different volumes of the virus stock can be tested. For example, volumes of $20,10,5$, and $2.5 \mu \mathrm{L}$ of $10^{8} \mathrm{pfu} / \mathrm{mL}$ virus would give MOI values of 10,5 , 2.5 , and $1.25 \mathrm{pfu} / \mathrm{cell}$, respectively, using this protocol. Label a 24 -well plate with the range of volumes across the six columns. Include a column for a positive control (a virus known to express to high levels at a given MOI) and a negative, no-virus control. The four rows will be harvested at different time points, for example, 1, 2, 3, and $4 \mathrm{~d}(24-96 \mathrm{~h})$ postinfection.

It is advisable to add $<20 \%$ virus volume to the total well volume.

If the MOI has been determined, for example, using Steps 27-40, then MOI values of 2, 4, 6, and 8 pfu/cell are a reasonable range to test.

High MOI values (5-10 pfu/cell) are usually best for synchronous infection, but very high MOI values may inhibit protein expression. If MOI values $>5$ are used, the medium should be checked for the protein of interest. After $5 d$ of infection at a high MOl, the majority of the cells should have lysed. If desired, the target protein can then be isolated from the media in a manner similar to a secreted protein (see Step 25).

17. Seed each well in the plate with $2 \times 10^{5}$ cells by adding $200 \mu \mathrm{L}$ of exponential-growth-phase cells that have been diluted to $10^{6}$ cells $/ \mathrm{mL}$. Allow the cells to attach for $60 \mathrm{~min}$ at room temperature, making sure the culture dishes are level.

18. While the cells are attaching, prepare the virus dilutions. Arrange five microcentrifuge tubes in a rack and label them as 30,20,10,5, and positive control. In the first tube (labeled 30), dilute the virus stock to $8 \times 10^{7} \mathrm{pfu} / \mathrm{mL}$ in $500 \mu \mathrm{L}$ of medium. Add $200 \mu \mathrm{L}$ of medium to each of the remaining tubes. Transfer $200 \mu \mathrm{L}$ of the diluted virus from the first tube to the next and mix well. Then transfer $200 \mu \mathrm{L}$ from the second tube to the third, mix well, and repeat for the third to fourth tubes. Dilute the positive control virus in the sixth tube to obtain an appropriate MOI (e.g., to $8 \times 10^{7} \mathrm{pfu} / \mathrm{mL}$ ) and a volume of $200 \mu \mathrm{L}$ or more. Be careful not to contaminate the negative control with virus or to cross-contaminate the experimental and positive control samples.

19. After the cells have attached, transfer $50 \mu \mathrm{L}$ from the first dilution of the recombinant virus to all four wells of the tissue culture plate (from Steps 16 and 17) in the column labeled " $30 \mu \mathrm{L}$. " Repeat

\section{BOX 3. ENHANCING EXPRESSION USING TN-5 (HIGH-FIVE)}

Several variations can enhance expression when Tn-5 (High-Five) insect cells are used as the host strain.

1. During propagation and maintenance of Tn-5 cultures, an appropriate medium (e.g., ESF 921 from Expression Systems) includes $25 \mathrm{mg} / \mathrm{mL}$ dextran sulfate (molecular weight 9000-20,000 Da; SigmaAldrich, catalog no. D6924) to avoid cell clumping.

2. Infection at high cell density (as described below) reduces the dextran sulfate, which otherwise would inhibit the infection.

i. Centrifuge cells at $400 \mathrm{~g}$ for $10 \mathrm{~min}$ at $4^{\circ} \mathrm{C}$, then resuspend them to a cell density of $1.6 \times 10^{7}$ with an appropriate amount of the virus (to achieve an $\mathrm{MOI}$ of $1-4$ ) and expression medium lacking dextran sulfate.

ii. Rock the cells for $1 \mathrm{~h}$ at $130 \mathrm{rpm}$ and $27^{\circ} \mathrm{C}$, and then dilute the infected cells to a cell density of $2 \times$ $10^{6}$ with medium that lacks dextran sulfate.

iii. Continue expression in the conditions described proceeding from Step 24. 
C.L. Kielkopf et al.

for each of the remaining dilutions and the positive control. Leave the sixth column uninfected to serve as the negative control. Gently swirl the culture dishes to mix and place them at $28^{\circ} \mathrm{C}$.

20. Harvest the cells in the top row at $24 \mathrm{~h}$, second row at $48 \mathrm{~h}$, third row at $72 \mathrm{~h}$, and last row at $96 \mathrm{~h}$ postinfection. Loosen the cells with a stream of medium. Transfer the cells and medium to a microcentrifuge tube. Centrifuge at $1000 \mathrm{~g}$ for $10 \mathrm{~min}$ in a microcentrifuge to pellet the cells, and then carefully remove the supernatant. Resuspend each cell pellet in $50 \mu \mathrm{L}$ of $6 \times$ SDS loading buffer, heat the samples in an $85^{\circ} \mathrm{C}$ heat block for $2 \mathrm{~min}$, and then vortex vigorously. Centrifuge the tubes at maximum speed for $1 \mathrm{~min}$ at room temperature in a microcentrifuge, and store at $-20^{\circ} \mathrm{C}$ until all of the samples are collected and ready to load on a gel.

Monolayers of insect cells can be easily detached from a surface by a gentle flow of medium from a pipette.

21. After briefly rewarming the samples to $85^{\circ} \mathrm{C}$, load $\sim 40 \mu \mathrm{g}$ of each suspension on a suitable percentage SDS-polyacrylamide gel. In most cases, $5-10 \mu \mathrm{L}$ of sample is an appropriate volume to load. Stain the gel with Coomassie Brilliant Blue and/or perform an immunoblot to visualize the induced protein.

As a rule of thumb, 5000 insect cells contain $\sim 10 \mu \mathrm{g}$ of total protein.

If the protein is secreted, load $15 \mu \mathrm{L}$ of supernatant and analyze by immunoblotting.

In extracts of cells expressing the recombinant gene, a protein of the predicted molecular weight should be visible at some time point after induction. The kinetics of induction and the stability of the foreign protein may differ from those of the positive control. No corresponding band should be visible in the negative, novirus control.

\section{Large-Scale Expression of the Target Protein in Insect Cells}

22. For large-scale expression and purification of the target protein, expand the desired cell line for protein expression (e.g., SF-9, SF-21, Tn-5, or Mimic Sf-9 cells) to obtain $400 \mathrm{~mL}$ of suspension culture in exponential growth phase $\left(1.5-2.5 \times 10^{6}\right.$ cells $\left./ \mathrm{mL}\right)$. (For further details on insect cell culture, see Box 2.) For further details on using Tn- 5 cells, see Box 3.

23. Add a volume of viral stock to the expanded cells from Step 22 that results in an MOI of 4.0 (or an optimal volume determined in the section Small-Scale Test and Optimization of Target Protein Expression in Insect Cells, above). For example,

$$
\frac{\left[(400 \mathrm{~mL} \text { volume }) \times\left(2 \times 10^{6} \text { cells } / \mathrm{mL}\right) \times 4 \mathrm{pfu} / \mathrm{cell}\right]}{\left(4 \times 10^{8} \mathrm{pfu} / \mathrm{mL} \text { viral titer }\right)}=8 \mathrm{~mL} \text { of virus stock } .
$$

24. Four hours after adding the virus, exchange the spent medium for fresh medium. Centrifuge the cells at $400 \mathrm{~g}$ for $10 \mathrm{~min}$ at $4^{\circ} \mathrm{C}$. Discard the supernatant, and then gently resuspend the cells in $400 \mathrm{~mL}$ of fresh medium.

25. At $72 \mathrm{~h}$ postinfection (or an optimal time point determined in the previous section), collect the cells by centrifuging at $400 \mathrm{~g}$ for $10 \mathrm{~min}$. Discard the supernatant, gently resuspend the cell pellet in $5 \mathrm{~mL}$ of $1 \times$ PBS, and transfer the cells to a $50-\mathrm{mL}$ screw-cap tube. Pellet the cells again by centrifuging at $400 \mathrm{~g}$ for $10 \mathrm{~min}$. Either (i) discard the $1 \times$ PBS supernatant, flash-freeze the cell pellet in liquid nitrogen, and store it at $-80^{\circ} \mathrm{C}$, or (ii) proceed immediately with a purification protocol.

If the protein is secreted, collect the medium supernatant from the first centrifugation step. Transfer it to another tube and centrifuge at 30,000g for $1 \mathrm{~h}$ to remove the baculovirus particles and cell debris. Alternatively, clarify the supernatant by passing it through a $0.22-\mu m$ filter. Flash-freeze the supernatant for storage at $-80^{\circ} \mathrm{C}$, or proceed with a purification protocol. Before purification, it is advisable to remove contaminating media components before purification by dialysis into an appropriate buffer. Likewise, the supernatant should be concentrated $\sim 10$-fold to reduce the volume to a manageable quantity. 
26. Proceed to Protocol: Purification of Polyhistidine-Tagged Proteins by Immobilized Metal Affinity Chromatography (Kielkopf et al. 2020a) if the expressed protein contains a polyhistidine tag.

Proceed to Protocol: Purification of Fusion Proteins by Affinity Chromatography on Glutathione Resin (Kielkopf et al. 2020b) if the expressed protein is a fusion with glutathione S-transferase.

\section{Plaque Assay to Determine the Titer of the Baculovirus Stock}

Plaque or end point dilution assays are the traditional methods for isolating pure recombinant baculovirus, from which the stock is then derived, and for quantifying infectivity. The plaque assay originally described for animal cells (Dulbecco 1952) was modified for baculovirus-infected insect cells by Lee and Miller (1978). In the plaque assay, a cell monolayer is infected with virus and then overlaid with agarose to maintain the positions of the cells and limit the spread of the virus. At very low dilutions of virus, isolated cells become infected. The infected cell eventually lyses and releases virus, which then infects other cells in the immediate area. The lyses of infected cells lead to a region of clarity on the infected plate that corresponds to the progeny of a single baculovirus. These "plaques" may either be isolated for preparation of a clonal stock or counted at varying dilutions to determine the viral titer. Steps 27-40 describe the traditional plaque assay, as modified from King et al. (2007). For additional information, see Discussion.

27. Expand the Sf- 9 or Sf- 21 cells as described in Step 2 and Box 2 to provide $\sim 0.5 \times 10^{7}$ cells in exponential growth phase for each of the experimental samples and for the positive and negative (no-virus) controls.

Sf-21 cells are preferred for plaque assays because they produce distinct plaques in a shorter period of time. The use of serum-supplemented medium also enhances plaque visibility. Wherever possible, virus titers should be determined using the medium and cell strain planned for protein expression.

28. Label two six-well plates for each of the experimental and positive control samples. To ease pipetting, the columns should be identical, so the top and bottom rows of plate 1 are labeled $0,10^{-8}, 10^{-7}$, and the top and bottom rows of plate 2 are labeled $10^{-6}, 10^{-7}, 10^{-8}$. Seed each well with $0.9 \times 10^{6} \mathrm{Sf}-9$ or $1.4 \times 10^{6} \mathrm{Sf}-21$ cells in a $2-\mathrm{mL}$ volume of medium. Rock the plates immediately after each seeding to disperse the cells evenly. Allow the cells to attach for $60 \mathrm{~min}$ at room temperature making sure the culture dishes are level.

29. During this incubation period, prepare 10 -fold serial dilutions of the virus in the range $10^{-1}$ to $10^{-8}$. Include an additional tube for the negative (no-virus) control. Place $900 \mu \mathrm{L}$ of medium in the sterile, labeled microcentrifuge tubes. Add $100 \mu \mathrm{L}$ of virus to the tube labeled " $10^{-1}$ " and invert or gently vortex to mix thoroughly. Using a fresh pipette tip, transfer $100 \mu \mathrm{L}$ of the " $10^{-1}$ "

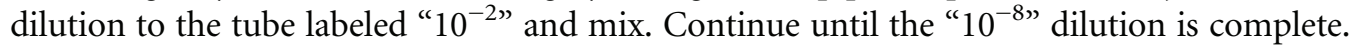

30. One hour after seeding the plates, check that the cells have attached in an even subconfluent monolayer, using an inverted microscope.

31. Arrange the virus dilutions and tissue culture plates in a sterile tissue culture hood. Remove the old medium from each well and immediately replace it with $0.5 \mathrm{~mL}$ of the appropriate dilution of the virus (in the $10^{-4}$ to $10^{-8}$ range for the P2 or P3 stocks, as labeled in Step 29). Include the novirus controls in the wells labeled " 0 ." Incubate the cells with virus for $60 \mathrm{~min}$.

32. Dispense $20 \mathrm{~mL}$ of $1 \times$ Insect cell culture medium in a $50-\mathrm{mL}$ sterile tube for each set of dilutions, and warm it in a $40^{\circ} \mathrm{C}$ water bath. Melt one $5-\mathrm{mL}$ aliquot of $5 \%$ low-melting-temperature agarose by microwaving briefly, then place it in a $40^{\circ} \mathrm{C}$ water bath.

If the baculoviral DNA contained a lacZ gene before recombination, add $240 \mu \mathrm{L}$ of $X$-Gal (final concentration of $240 \mu \mathrm{g} / \mathrm{mL}$ ) to the agarose mixture for blue/white screening of recombinant virus.

A dry heat block adapted for 50-mL tubes is helpful to avoid contamination at this step. Otherwise, be sure the water bath is clean, and wipe the outside of the removed tubes with ethanol.

33. About $15 \mathrm{~min}$ before the end of the insect cell/virus incubation, add the agarose solution to the warm medium and invert to mix thoroughly, while avoiding air bubbles and without allowing the solution to cool. The final mixture should be $1 \%$ agarose.

34. After $1 \mathrm{~h}$ of insect cell/virus incubation, carefully remove the medium from the cell monolayer by pipetting the medium from the side of the inclined plate. Gently pipette $2 \mathrm{~mL}$ of agarose medium 
C.L. Kielkopf et al.

mixture down one side of the dish to cover the cell monolayer. Allow the agarose overlay to solidify at room temperature with the plate on a level surface (30-60 min).

35. Add an additional $1 \mathrm{~mL}$ of Insect cell culture medium as an overlay to feed the cultures. Incubate at $28^{\circ} \mathrm{C}$ until the cell monolayer has reached confluence $(4-7 \mathrm{~d})$.

36. Plaques may be visible as clear zones when the plates are placed on a dark surface and exposed to a bright light or viewed at a tilted angle against a bright light. These can be made more apparent by staining the dishes with Neutral Red. The plaques then become clear zones in a red background.

If the parental virus contained a lacZ gene that was replaced by the gene of interest, then plaques of recombinant virus should not be colored, but those of nonrecombinant virus will appear faintly blue.

37. To stain with Neutral Red, remove the liquid overlay from the plate. Replace with $1 \mathrm{~mL}$ of diluted Neutral Red, prepared by adding $50 \mu \mathrm{L}$ of the Neutral Red stock ( $5 \mathrm{mg} / \mathrm{mL}$ in water) to $950 \mu \mathrm{L}$ of sterile $1 \times$ PBS. Incubate a few hours or overnight at $28^{\circ} \mathrm{C}$.

38. The next morning, tip off the stain and invert the dishes to blot on tissue or filter paper. Replace the lids, and leave the plates inverted in the dark for a few hours for the plaques to clear.

39. Select a dilution that has produced 10-30 plaques, and count the plaques for the duplicate wells. Determine the average number of plaques for that dilution, and calculate the virus titer as follows:

$$
\text { Titer of virus }(\mathrm{pfu} / \mathrm{mL})=\frac{(\text { Average number of plaques })}{(\text { Dilution }) \times 0.5 \mathrm{~mL}} \text {, }
$$

where $5 \mathrm{~mL}$ is the volume of diluted virus that was added to the plate, in milliliters. For example, for a viral titer of $10^{7} \mathrm{pfu} / \mathrm{mL}, 20$ plaques are expected on the $10^{-6}$ dilution plate.

40. To pick a plaque for generation of a clonal stock, insert the tip of a sterile Pasteur pipette in the center of the plaque, and with gentle suction draw out a plug of agarose. Place the plug in $1 \mathrm{~mL}$ of medium and vortex well to release the virus particles. Several plaques should be selected. These isolates may now be rescreened by a second plaque assay before amplification.

\section{Production of Bacmid DNA for Transfection into Insect Cells}

This series of steps uses molecular biology techniques to produce recombinant baculovirus DNA in E. coli before transfection of insect cells (Luckow et al. 1993). All reagents are marketed commercially as the Bac-to-Bac system from Life Technologies.

41. Construct and transform a pFastBac plasmid containing the target gene into competent DH10Bac cells (Life Technologies). Plate serial dilutions of the transformants $\left(10^{-1}\right.$ to $\left.10^{-3}\right)$ on LB agar plates containing the additions listed in the Reagents list above for selection. Incubate for $2 \mathrm{~d}$ at $37^{\circ} \mathrm{C}$ to allow the blue color to develop in the nonrecombinant colonies.

Because recombination of the pFastBac insert with baculovirus DNA in the DH10Bac cells interrupts a $\beta$ galactosidase coding region, recombinant colonies no longer produce a blue color when grown on X-Gal/ IPTG-containing media.

The pFastBac vectors are available for use with restriction enzymes, TOPO, or Gateway cloning strategies.

42. Analyze three to five isolated, large, white colonies by colony PCR to verify that the target gene is present.

43. Isolate the bacmid DNA using a standard alkaline lysis procedure. Be sure to maintain $50 \mu \mathrm{g} / \mathrm{mL}$ kanamycin and $7 \mu \mathrm{g} / \mathrm{mL}$ gentamicin in the LB medium used for growth of bacteria containing the recombinant bacmid.

\footnotetext{
Addition of tetracycline is not strictly necessary because the transposase function is no longer required at this stage.

Solutions containing bacmid DNA should be flicked gently to mix; repeated pipetting or vortexing will shear the large DNA.
} 
Problem: There is low protein expression.

Solution: Low protein expression using the baculovirus expression system may result from several factors. To improve protein expression, the MOI and time of infection can be optimized as described in the section Small-Scale Test and Optimization of Target Protein Expression in Insect Cells. Large differences in expression levels also may be observed following variations of the insect cell lines, growth medium, and fusion tags. Comprehensive lists of possible problems and solutions for baculovirus expression in insect cells are given in the BaculoGold (BD Biosciences) and Bac-to-Bac (Life Technologies) manufacturer's manuals.

Problem: The expression cassette is lost after multiple passages of viral stocks.

Solution: Substitute a stock of low-passage (P1-P2) virus.

Problem: Insect cells in continuous culture may lose their ability to express foreign proteins efficiently. Solution: Substitute a stock of low-passage insect cells.

Problem: The foreign protein may be toxic to the insect host cell.

Solution: Harvest the infected cells earlier.

Problem: The foreign protein may be degraded by the insect cell.

Solution: This possibility can be distinguished by comparing mRNA with protein levels.

\section{DISCUSSION}

Before transfection, standard molecular biology methods are used to place a target gene under control of a viral promoter carried in an E. coli vector. This construct is then transferred into the DNA of a baculovirus vector by homologous recombination. Although the major downstream steps remain the same, a variety of strategies are available for achieving recombination between the transfer vector and the viral DNA. These approaches range from cotransfection to recombination in E. coli hosts or in vitro.

In most cases, recombination with the transfer vector rescues a lethal deletion within the recipient viral DNA. Traditionally, several rounds of restriction digestion and purification were used to produce a deletion within a linearized viral DNA (Kitts and Possee 1993). A downside of this approach is that not every molecule of viral DNA is cut, with the result that a few nonrecombinant baculoviruses are likely to contaminate the viral progeny. Consequently, a time-consuming viral plaque assay was needed to isolate the recombinant baculovirus. Relief came with the advent of viral bacmid DNAs, which include the flashBAC (Oxford Technologies) or BacMagic (Merck) systems for recombination during cotransfection, or the Bac-to-Bac (Life Technologies) system for recombination in an E. coli host before transfection. Because these viral bacmid DNAs lack essential viral genes yet can be propagated in E. coli hosts, there is no risk of contamination by nonrecombinant baculovirus (Zhao et al. 2003). As such, plaque assays are not required to separate the recombinant from the parental virus. Instead, it is possible to proceed directly to amplifying the P1 viral stock or protein expression (Step 9). However, it remains important to quantify the viral titer to achieve optimal and reproducible expression of target proteins. Accordingly, an additional protocol is given for the viral plaque assay above.

The viral plaque assay often presents a challenge to novices, particularly when distinct plaque morphologies caused by replacement of the polyhedrin gene with an open reading frame (ORF) of interest are used to identify the recombinant baculovirus. Although this distinction is needed only when wild-type baculoviral DNA (rather than DNA with a lethal deletion) is used for 
C.L. Kielkopf et al.

recombination, viral plaques often are difficult for a novice to identify in general. The Neutral Red stain enhances plaque visibility by selectively staining living cells, whereas the infected regions remain clear. An end point dilution assay is an alternative to the plaque assay (for an excellent protocol, see Harwood 2007). However, both of these approaches suffer from the drawback of requiring 6-7 d to complete. More time-effective approaches for virus quantification, including antibody-based staining, flow cytometry, and quantitative real-time PCR, have been developed (Kitts and Green 1999; Kwon et al. 2002; Shen et al. 2002; Hitchman et al. 2007) and are marketed commercially (e.g., the BacPAK titer kits from ClonTech). Although these commercial assays can be completed in $<2 \mathrm{~d}$, they do not directly test virus infectivity and are not designed for isolating a single viral clone.

Coomassie Brilliant Blue R-250 Stain Solution

\begin{tabular}{lcc} 
Reagent & Quantity (for $100 \mathrm{~mL}$ ) & Final concentration \\
\hline Coomassie Brilliant Blue R-250 & $0.05 \mathrm{~g}$ & $0.05 \%$ \\
Methanol & $50 \mathrm{~mL}$ & $50 \%(\mathrm{v} / \mathrm{v})$ \\
Glacial acetic acid & $10 \mathrm{~mL}$ & $10 \%(\mathrm{v} / \mathrm{v})$
\end{tabular}

$\mathrm{H}_{2} \mathrm{O}$

to $100 \mathrm{~mL}$

Dissolve the Coomassie Brilliant Blue R-250 dye, and then filter through a Whatman No. 1 filter to remove any particulate matter. Can be stored at room temperature.

LB (Luria-Bertani) Liquid Medium

\begin{tabular}{lc} 
Reagent & Amount to add \\
\hline $\mathrm{H}_{2} \mathrm{O}$ & $950 \mathrm{~mL}$ \\
Tryptone & $10 \mathrm{~g}$ \\
$\mathrm{NaCl}$ & $10 \mathrm{~g}$ \\
Yeast extract & $5 \mathrm{~g}$
\end{tabular}

Combine the reagents and shake until the solutes have dissolved. Adjust the $\mathrm{pH}$ to 7.0 with $5 \mathrm{~N} \mathrm{NaOH}(\sim 0.2 \mathrm{~mL})$. Adjust the final volume of the solution to $1 \mathrm{~L}$ with $\mathrm{H}_{2} \mathrm{O}$. Sterilize by autoclaving for $20 \mathrm{~min}$ at $15 \mathrm{psi}\left(1.05 \mathrm{~kg} / \mathrm{cm}^{2}\right)$ on liquid cycle.

For solid medium, see the recipe entitled "Media containing agar or agarose."

\section{Media Containing Agar or Agarose}

Prepare liquid media according to the recipe given. Just before autoclaving, add one of the following:

Bacto agar (for plates)

Bacto agar (for top agar)

Agarose (for plates)

Agarose (for top agarose)
$15 \mathrm{~g} / \mathrm{L}$

$7 \mathrm{~g} / \mathrm{L}$

$15 \mathrm{~g} / \mathrm{L}$

$7 \mathrm{~g} / \mathrm{L}$

Sterilize by autoclaving for $20 \mathrm{~min}$ at $15 \mathrm{psi}\left(1.05 \mathrm{~kg} / \mathrm{cm}^{2}\right)$ on liquid cycle. When the medium is removed from the autoclave, swirl it gently to distribute the melted agar or agarose evenly throughout the solution. Be careful! The fluid may be superheated and may boil over when swirled. Before adding thermolabile substances (e.g., antibiotics), allow the medium to cool to $50^{\circ} \mathrm{C}-60^{\circ} \mathrm{C}$, and mix the medium by swirling to avoid producing air bubbles. 
Before pouring the plates, set up a color code (e.g., two red stripes for LB-ampicillin plates; one black stripe for LB plates, etc.), and mark the edges of the plates with the appropriate colored markers. Pour plates directly from the flask; allow $\sim 30-35 \mathrm{~mL}$ of medium per $90-\mathrm{mm}$ plate. To remove bubbles from the medium in the plate, flame the surface of the medium with a Bunsen burner before the agar or agarose hardens. When the medium has hardened completely, invert the plates and store them at $4^{\circ} \mathrm{C}$ until needed.

The plates should be removed from storage $1-2 \mathrm{~h}$ before they are used. If the plates are fresh, they will "sweat" when incubated at $37^{\circ} \mathrm{C}$. When this condensation drops on the agar/agarose surface, it allows bacterial colonies or bacteriophage plaques to spread and increases the chances of cross-contamination. This problem can be avoided by wiping off the condensation from the lids of the plates and then incubating the plates for several hours at $37^{\circ} \mathrm{C}$ in an inverted position before they are used. Alternatively, remove the liquid by shaking the lid with a single, quick motion. To minimize the possibility of contamination, hold the open plate in an inverted position while removing the liquid from the lid.

Phosphate-Buffered Saline (PBS)

Final

Amount to add

Reagent (for $1 \times$ solution)

$(1 \times)$ concentration

$37 \mathrm{~ms}$

$\mathrm{NaCl}$
$\mathrm{KCl}$

$\mathrm{Na}_{2} \mathrm{HPO}_{4}$

$\mathrm{KH}_{2} \mathrm{PO}_{4}$

$8 \mathrm{~g}$

$0.2 \mathrm{~g}$

$1.44 \mathrm{~g}$

$0.24 \mathrm{~g}$
$2.7 \mathrm{~mm}$

$10 \mathrm{~mm}$

$1.8 \mathrm{~mm}$
Amount to add (for $10 \times$ stock)
Final

concentration $(10 \times)$

$1.37 \mathrm{M}$

$27 \mathrm{~mm}$

$2 \mathrm{~g}$

$14.4 \mathrm{~g}$

$2.4 \mathrm{~g}$

$100 \mathrm{~mm}$

$18 \mathrm{~mm}$

If necessary, PBS may be supplemented with the following:
$\mathrm{CaCl}_{2} \cdot 2 \mathrm{H}_{2} \mathrm{O}$
$0.133 \mathrm{~g}$
$1 \mathrm{~mm}$
$1.33 \mathrm{~g}$
$10 \mathrm{~mm}$
$\mathrm{MgCl}_{2} \cdot 6 \mathrm{H}_{2} \mathrm{O}$
$0.10 \mathrm{~g}$
$0.5 \mathrm{~mm}$
$1.0 \mathrm{~g}$
$5 \mathrm{~mm}$

PBS can be made as a $1 \times$ solution or as a $10 \times$ stock. To prepare $1 \mathrm{~L}$ of either $1 \times$ or $10 \times \mathrm{PBS}$, dissolve the reagents listed above in $800 \mathrm{~mL}$ of $\mathrm{H}_{2} \mathrm{O}$. Adjust the $\mathrm{pH}$ to 7.4 (or 7.2, if required) with $\mathrm{HCl}$, and then add $\mathrm{H}_{2} \mathrm{O}$ to $1 \mathrm{~L}$. Dispense the solution into aliquots and sterilize them by autoclaving for $20 \mathrm{~min}$ at $15 \mathrm{psi}\left(1.05 \mathrm{~kg} / \mathrm{cm}^{2}\right)$ on liquid cycle or by filter sterilization. Store PBS at room temperature.

\section{ACKNOWLEDGMENTS}

We thank Jost Vielmetter of the Caltech Protein Expression Facility for assistance with this protocol along with his colleague Inderjit Nangiana for Figure 1.

\section{REFERENCES}

Agathos SN. 2007. Development of serum-free media for lepidopteran insect cell lines. Methods Mol Biol 388: 155-186.

Altmann F, Schwihla H, Staudacher E, Glossl J, Marz L. 1995. Insect cells contain an unusual, membrane-bound $\beta$ - $N$-acetylglucosaminidase probably involved in the processing of protein $\mathrm{N}$-glycans. J Biol Chem 270: 17344-17349.

Aumiller JJ, Hollister JR, Jarvis DL. 2003. A transgenic insect cell line engineered to produce CMP-sialic acid and sialylated glycoproteins. Glycobiology 13: 497-507.

Barry GF. 1988. A broad-host-range shuttle system for gene insertion into the chromosomes of Gram-negative bacteria. Gene 71: 75-84.

Burand JP, Summers MD, Smith GE. 1980. Transfection with baculovirus DNA. Virology 101: 286-290.
Davis TR, Wickham TJ, McKenna KA, Granados RR, Shuler ML, Wood HA. 1993. Comparative recombinant protein production of eight insect cell lines. In Vitro Cell Dev Biol Anim 29A: 388-390.

Dee KU, Shuler ML, Wood HA. 1997. Inducing single-cell suspension of BTI-TN5B1-4 insect cells: I. The use of sulfated polyanions to prevent cell aggregation and enhance recombinant protein production. Biotechnol Bioeng 54: 191-205.

Dulbecco R. 1952. Production of plaques in monolayer tissue cultures by single particles of an animal virus. Proc Natl Acad Sci 38: $747-752$.

Gardiner GR, Stockdale H. 1975. Two tissue culture media for production of lepidopteran cells and nuclear polyhedrosis virus. J Invertebr Pathol 25: 363-370. 


\section{C.L. Kielkopf et al.}

Gimpl G, Klein U, Reilander H, Fahrenholz F. 1995. Expression of the human oxytocin receptor in baculovirus-infected insect cells: Highaffinity binding is induced by a cholesterol-cyclodextrin complex. Biochemistry 34: 13794-13801.

Grace TD. 1962. Establishment of four strains of cells from insect tissues grown in vitro. Nature 195: 788-789.

Granados RR, Derksen AC, Dwyer KG. 1986. Replication of the Trichoplusia ni granulosis and nuclear polyhedrosis viruses in cell cultures. Virology 152: $472-476$

Harwood S. 2007. Small-scale protein production with the baculovirus expression vector system. Methods Mol Biol 388: 211-224.

Hink WF. 1970. Established insect cell line from the cabbage looper, Trichoplusia ni. Nature 226: 466-467.

Hitchman RB, Siaterli EA, Nixon CP, King LA. 2007. Quantitative real-time PCR for rapid and accurate titration of recombinant baculovirus particles. Biotechnol Bioeng 96: 810-814.

Hollister J, Grabenhorst E, Nimtz M, Conradt H, Jarvis DL. 2002. Engineering the protein $\mathrm{N}$-glycosylation pathway in insect cells for production of biantennary, complex $N$-glycans. Biochemistry 41: 15093-15104.

Jarvis DL, Kawar ZS, Hollister JR. 1998. Engineering N-glycosylation pathways in the baculovirus-insect cell system. Curr Opin Biotechnol 9: 528-533.

Kielkopf CL, Bauer W, Urbatsch IL. 2020a. Purification of polyhistidinetagged proteins by immobilized metal affinity chromatography. Cold Spring Harb Protoc doi:10.1101/pdb.prot102194.

Kielkopf CL, Bauer W, Urbatsch IL. 2020b. Purification of fusion proteins by affinity chromatography on glutathione resin. Cold Spring Harb Protoc doi:10.1101/pdb.prot102202.

King LA, Hitchman R, Possee RD. 2007. Recombinant baculovirus isolation. Methods Mol Biol 388: 77-94.

Kitts PA, Green G. 1999. An immunological assay for determination of baculovirus titers in 48 hours. Anal Biochem 268: 173-178.

i Kitts PA, Possee RD. 1993. A method for producing recombinant baculovirus expression vectors at high frequency. BioTechniques 14: 810-817.
Kwon MS, Dojima T, Toriyama M, Park EY. 2002. Development of an antibody-based assay for determination of baculovirus titers in 10 hours. Biotechnol Prog 18: 647-651.

Lee HH, Miller LK. 1978. Isolation of genotypic variants of Autographa californica nuclear polyhedrosis virus. J Virol 27: 754-767.

Licari P, Bailey JE. 1991. Factors influencing recombinant protein yields in an insect cell-baculovirus expression system: Multiplicity of infection and intracellular protein degradation. Biotechnol Bioeng 37: 238-246.

Luckow VA, Lee SC, Barry GF, Olins PO. 1993. Efficient generation of infectious recombinant baculoviruses by site-specific transposon-mediated insertion of foreign genes into a baculovirus genome propagated in Escherichia coli. J Virol 67: 4566-4579.

Lynn DE. 2002. Methods for maintaining insect cell cultures. J Insect Sci 2: 9

Lynn DE. 2007. Available lepidopteran insect cell lines. Methods Mol Biol 388: $117-138$.

O’Reilly DR, Miller LK, Luckow VA. 1994. Baculovirus expression vectors. Oxford University Press, New York.

Shen CF, Meghrous J, Kamen A. 2002. Quantitation of baculovirus particles by flow cytometry. J Virol Methods 105: 321-330.

Vaughn JL, Goodwin RH, Tompkins GJ, McCawley P. 1977. The establishment of two cell lines from the insect Spodoptera frugiperda (Lepidoptera; Noctuidae). In Vitro 13: 213-217.

Wadzinski BE, Eisfelder BJ, Peruski LF Jr, Mumby MC, Johnson GL. 1992. $\mathrm{NH}_{2}$-terminal modification of the phosphatase 2A catalytic subunit allows functional expression in mammalian cells. J Biol Chem 267: 16883-16888.

Wickham TJ, Nemerow GR. 1993. Optimization of growth methods and recombinant protein production in BTI-Tn-5B1-4 insect cells using the baculovirus expression system. Biotechnol Prog 9: 25-30.

Wickham TJ, Davis T, Granados RR, Shuler ML, Wood HA. 1992. Screening of insect cell lines for the production of recombinant proteins and infectious virus in the baculovirus expression system. Biotechnol Prog 8: 391-396

Zhao Y, Chapman DA, Jones IM. 2003. Improving baculovirus recombination. Nucleic Acids Res 31: e66. 


\section{Expression of Cloned Genes Using the Baculovirus Expression System}

Clara L. Kielkopf, William Bauer and Ina L. Urbatsch

Cold Spring Harb Protoc; doi: 10.1101/pdb.prot102152 originally published online April 30, 2020

\begin{tabular}{|c|c|}
\hline $\begin{array}{r}\text { Email Alerting } \\
\text { Service }\end{array}$ & Receive free email alerts when new articles cite this article - click here. \\
\hline $\begin{array}{r}\text { Subject } \\
\text { Categories }\end{array}$ & $\begin{array}{l}\text { Browse articles on similar topics from Cold Spring Harbor Protocols. } \\
\text { Cell Biology, general (1382 articles) } \\
\text { DNA Delivery/Gene Transfer ( } 344 \text { articles) } \\
\text { DNA Delivery/Gene Transfer, general (341 articles) } \\
\text { Expression of Cloned Genes ( } 80 \text { articles) } \\
\text { Molecular Biology, general (1293 articles) } \\
\text { Protein Expression and Interactions (93 articles) }\end{array}$ \\
\hline
\end{tabular}

